\title{
放電スイッチを用いない軸方向放電励起気体レーザー
}

\author{
田中 美憂 ${ }^{1}$, 丁 正也 ${ }^{1}$, 宇野 和行 ${ }^{2}$, 津山 美穂 ${ }^{1}$, 中野 人志 ${ }^{1}$ \\ ${ }^{1}$ 近畿大学 理工学部電気電子工学科 ( \\ ${ }^{2}$ 山梨大学 工学部電気電子工学科 ( $\bar{T} 400-8511$ 山梨県甲府市武田4-3-11)
}

\section{Development of a Longitudinally Excited Gas Laser without Discharge Switch}

\author{
Miyu TANAKA ${ }^{1}$, Masaya TEI ${ }^{1}$, Kazuyuki UNO ${ }^{2}$, Miho TSUYAMA ${ }^{1}$, and Hitoshi NAKANO ${ }^{1}$ \\ ${ }^{1}$ Department of Electrical and Electronic Engineering, Faculty of Science and Engineering, Kindai University, \\ 3-4-1 Kowakae, Higashiosaka, Osaka 577-8502 \\ ${ }^{2}$ Department of Electrical and Electronic Engineering, Faculty of Engineering, University of Yamanashi, \\ 4-3-11 Takeda, Kohu, Yamanashi 400-8511
}

(Received November 1, 2016)

\begin{abstract}
We developed a longitudinally excited $\mathrm{CO}_{2}$ laser without a discharge switch and installed a fast highvoltage solid state switch that consists of a series of connected MOSFETs to a longitudinally excited $\mathrm{CO}_{2}$ laser as a spiker for sustaining the discharge. Laser oscillation was successfully achieved at a spiker voltage of $5 \mathrm{kV}$ with a rise time of $40 \mathrm{~ns}$. Several mJs of laser energy were stably obtained.
\end{abstract}

Key Words: Fast high-voltage switch, Longitudinally excited gas laser

1. はじめに

レーザー加工に用いるレーザー装置は, 一般に大型で 高価であり，付加価值の高い応用にのみ適用されてい る、レーザーを中小企業等での部品製作等, 幅広い産業 分野に普及させるためには，レーザーの低コスト化，操 作性の簡便さ，装置の耐環境性向上等の可能性を追求す ることが必要である。気体レーザーは，その耐環境性の 高さ, 高出力性等により, 古くから加工用レーザーとし て広く用いられている。しかしながら、レーザーを安定 に高繰り返し使用するには高速ガスフロー, 予備電離シ ステム等の追加が必要であり, レーザーのコスト上昇を まねくとともに, 装置操作性の低下, メンテナンスの頻 度が増加する等, 産業応用に適した状況にあるとは言い 難い.

筆者らが産業応用に理想的な特長を有するレーザーと して着目したのが軸方向放電励起気体レーザーであ る る $^{1-4)}$ 軸方向放電励起気体レーザーは，レーザーが出力 する方向と同方向に放電を行う励起方式を採用している レーザーである. 通常, 数十 $\mathrm{cm}$ の誘電体チューブを放電 管として用い，放電管の両端に電極を配置し，電極の部 分に共振器用ミラーを取り付けた構造となってい

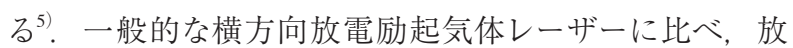
電長が長くなるため, 軸方向放電励起気体レーザーは低 ガス圧下 $(10 \mathrm{kPa}$ 以下 $)$ に扔いても高い放電開始電圧 $(20$

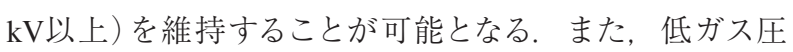
下では, 電子のドリフト速度が大きくなるので, 予備電離
を用いずに均一放電を得ることができる。 さらに，ス卜 リーマ放電が管内を均一に拡散して進展していくため, 高 速ガスフローを必要とせずに，高い繰り返し動作が可能 となる，つまり，軸方向放電励起レーザーでは，横方向 放電励起気体レーザーで必要であった予備電離装置が不 要であり, 小型で単純, 安価な装置構成が可能となる.

軸方向放電励起気体レーザーの電源部では，しかしな がら，主にギャップスイッチ等の放電スイッチによって 大電流のスイッチングが行われており，レーザー出力の 安定性低下, 放電による電極の劣化に起因した短寿命化 や低繰り返し周波数にしか対応できないといった問題が 生じている。電源部への固体スイッチ導入は技術的に可 能ではあるが, 現状, 極端に高価であるため, レーザー の低コスト化には貢献できていない.

本研究では, 放電スイッチを用いない軸方向放電励起 気体レーザーの実現を目的とした。高速高電圧スパイク 電圧を放電管に印加することによって管内の放電インピー ダンスを下げ，主放電の発生を促し，外部回路によって 放電を維持する単純な装置構成を考案した。レーザー装 置全体の低コスト化, 安定性・メンテナンス性の向上,さ らに沉用性の拡大のため, 安価で容易に入手可能なパ ワー半導体を用いて高速高電圧固体スイッチを作製し, これを高速高電圧スパイク電圧発生源として利用した。

\section{2. 装置の構成}

レーザー装置は, Fig. 1 に示すように，高圧直流電 


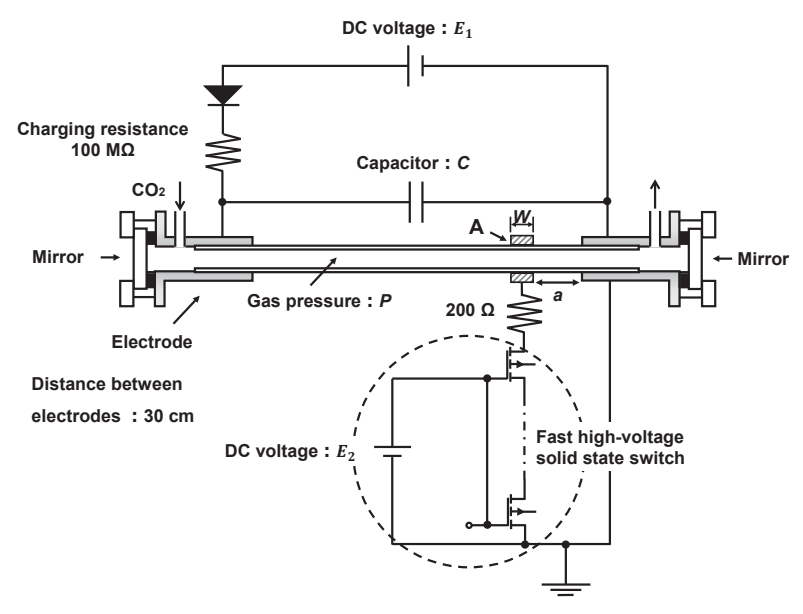

Fig. 1 Schematic illustration of longitudinally excited gas laser coupled with fast high-voltage solid state switch.

源, 充電抵抗およびキャパシタを含む電源回路, 両端に 電極を取り付けたパイレックスガラス製の放電管で構成 されている，放電管には, 中間電極 $\mathrm{A}($ 長さW: $1.5 \mathrm{~cm})$ が 設けられ，高速高電圧固体スイッチが接続されている。

高圧直流電源によってキャパシタCが充電され，放電 管に電圧が印加される。中間電極Aに接続された高速高 電圧固体スイッチを動作させることで, 中間電極 $\mathrm{A}$ と放 電管ならびにアース電極との間に形成されるキャパシタ の放電が管内の主放電発生を促す。この方式では放電管 そのものが高電圧スイッチとして動作するため, 電源部 のスイッチが不要となる.

本研究においては, 比較的高効率発振が可能で産業応 用範囲の広い, 炭酸ガスレーザー(波長 $10.6 \mu \mathrm{m})$ の発振 を目指した。 内径 $13 \mathrm{~mm}$, 長さ30 $\mathrm{cm}$ の放電管内にレー ザーガス $\left(\mathrm{CO}_{2}: 7 \%, \mathrm{~N}_{2}: 14 \%, \mathrm{He}: 79 \%\right)$ を充填した。放電 管の端部に波長 $10.6 \mu \mathrm{m}$ に対して全反射および反射率 $70 \%$ のラー対を取り付け, 光共振器を構成した。

\section{3. 高速高電圧固体スイッチ}

Fig. 2 に高速高電圧固体スイッチ回路の詳細を示す. 半導体デバイスとしては高耐圧で高速性に優れ, さらに 安価で入手し易いMOSFET(2SK3301)を用いた。 MOSFETを高速動作させるためには低出力インピーダンスの ゲート回路が有効であるが, 本研究ではアバランシェト ランジスタスイッチ回路をゲートに接続した。 アバラン シェトランジスタスイッチ回路から出力されるナノ秒 オーダの高速高電圧パルスがMOSFETの入力容量を急速 に充電することによって，ドレインーソース間を高速で 導通させることができる。

回路の高耐圧化には, MOSFETを直列接続することで 対応した，回路のコスト上昇を防ぐため，単一のゲート 回路でMOSFETを多段動作させた ${ }^{6)}$.

Fig. 2 において, 高圧直流電源によってMOSFETに高 電圧を印加すると, 同時にコンデンサ $\mathrm{C}_{2}-\mathrm{C}_{5}$ が充電され る。アバランシェトランジスタ回路からのナノ秒オーダ

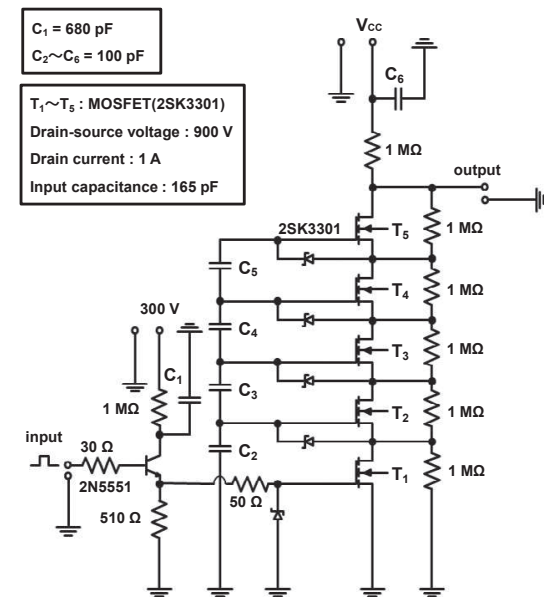

Fig. 2 Circuit of fast high-voltage solid state switch for use in the longitudinally excited gas laser.

の高速パルスが一段目のMOSFET $\left(\mathrm{T}_{1}\right)$ のゲートに入力さ れると, $\mathrm{T}_{1}$ が高速で導通する。 $\mathrm{T}_{1}$ が導通すると, 二段目 のMOSFET $\left(\mathrm{T}_{2}\right)$ のゲートとソース間に電位差が生じ, $\mathrm{T}_{2}$ のゲートに接続されているキャパシタ $\mathrm{C}_{2}$ の放電が開始さ れ，それがしきい電圧の值を超えると， $\mathrm{T}_{2}$ が導通する。 $\mathrm{T}_{3}-\mathrm{T}_{5}$ も順に同様に導通していく.

高速高電圧固体スイッチの典型的なスイッチング波形 をFig. 3 に示す. $5 \mathrm{kV}$ の印加電圧においてのスイッチン グ速度は10-90\%で約40 nsであった。

\section{4. 実験方法}

実験においては, 充電電圧 $E_{1}$, キャパシ夕容量 $C$, ガ ス圧力 $P$, 中間電極 $\mathrm{A}$ とアース電極との距離 $a$ をパラメー 夕とした Fig. 1 参照)。適当な電圧でキャパシタCを充 電後, 高速高電圧固体スイッチを動作させ，放電の有無 を調べた。放電が生じた際，感熱紙のバーンパターンに よってレーザー発振の有無を確認した。 また, パワー メータによってレーザーのエネルギーを測定した。

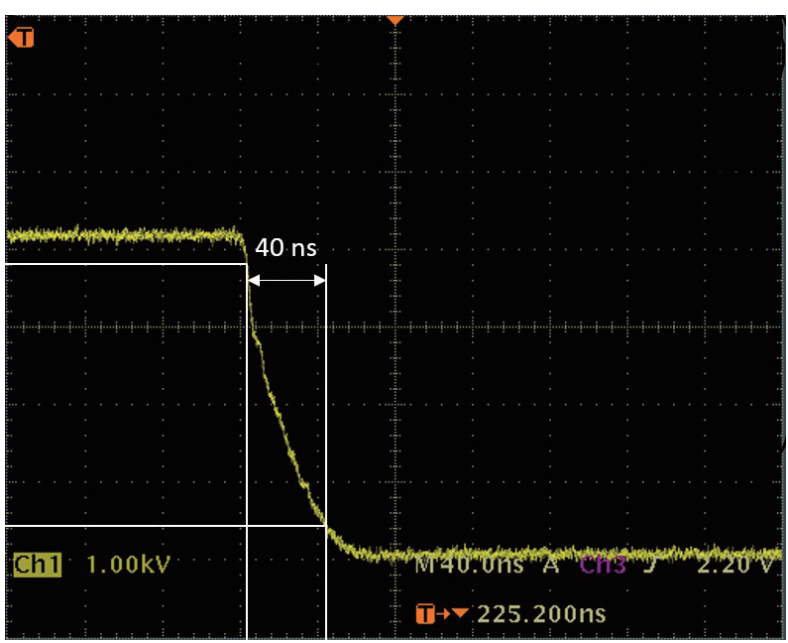

Fig. 3 Switching waveform of fast high-voltage solid state switch at the charging voltage of $5 \mathrm{kV}$. 


\section{5. 実験結果と考察}

本方式では, 充電電圧 $10-15 \mathrm{kV}$, ガス圧2-6 kPaの広 い範囲でレーザー発振に成功した。高速高電圧固体ス イッチの電圧は, 全ての実験において，5kV一定とし た。従来までの軸方向放電励起炭酸ガスレーザーはレー ザー発振に20-40 kV程度の電圧を要するが5), 本方式で は比較的低電圧でのレーザー発振が実現された。高速高 電圧固体スイッチからのスパイク電圧によって, 外部回 路の動作時には既に絶縁破壊が生じており，低電圧の レーザー発振が可能であったと思われる。

充電電圧 $E_{1}=10 \mathrm{kV}$, ガス圧 $P=3 \mathrm{kPa}$ と一定とし, キャパシタ容量 $C$ を $570 \mathrm{pF}$ か $2700 \mathrm{pF}$ 変化させた場合 のレーザーエネルギーの変化をFig. 4 に示す. Fig. 4 に おいて, 横軸は $1 / 2\left(\mathrm{CE}^{2}\right)$ で求められる静電エネルギーで 示している.レーザーエネルギーは静電エネルギーに比 例して増加していることが判る。本実験範囲で得られた 最大エネルギーは $9.5 \mathrm{~mJ}$ であり, エネルギー変換効率は $7.1 \%$ のきさとなった.

Fig. 5 には充電電圧 $10 \mathrm{kV}$, キャパシタ容量 $C$ を $700 \mathrm{pF}$ 一定とした際の, レーザーエネルギーと炭酸ガスの圧力

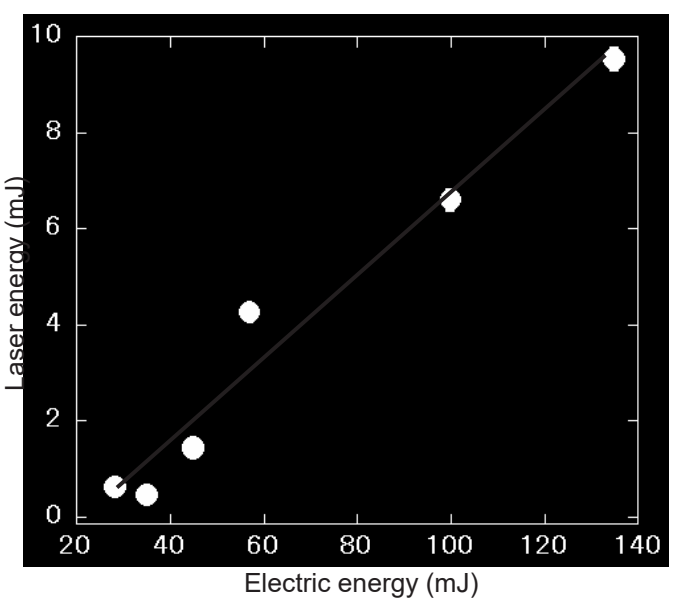

Fig. 4 The relation between electric energy and laser energy.

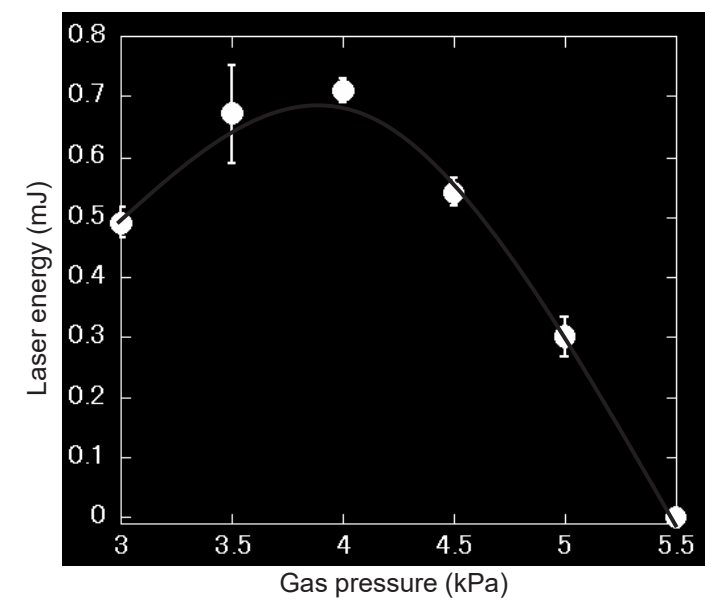

Fig. 5 The relation between gas pressure and laser energy.

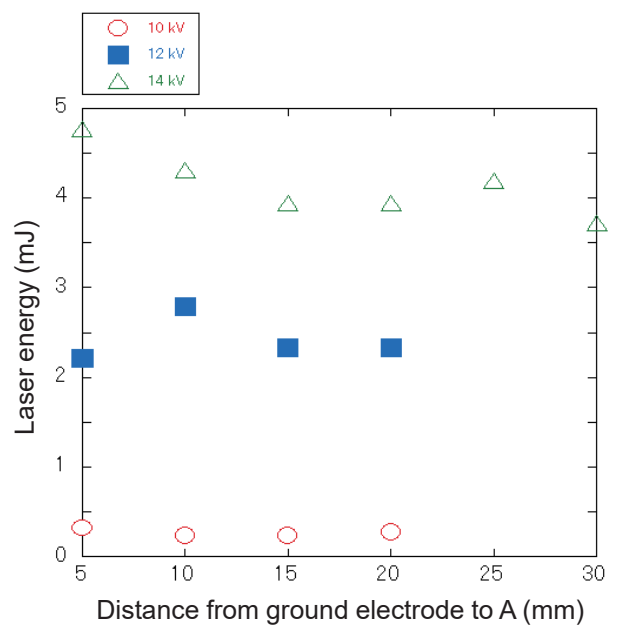

Fig. 6 Relation between distance from ground to intermediate electrodes and laser energy.

$P$ との関係を示している. $4 \mathrm{kPa}$ 辺りの圧力で最大エネル ギーが得られていることが判る，本実験条件では，電界 傾度の最適值が4 $\mathrm{kPa}$ 辺りのガス圧において達成される ことが判った。

中間電極 $\mathrm{A}$ とアース電極との距離 $a$ を変化させると, 放電の様相は変化した. Fig. 6 に充電電圧10, 12, 14 $\mathrm{kV}$ におけるレーザーエネルギーと中間電極ーアース電 極間との距離の関係を示す。充電電圧 $10 \mathrm{kV}$ およ゙ $12 \mathrm{kV}$ においては, 電極間距離が2 $20 \mathrm{~mm}$ 以上なると放電が生 じなくなったため, 放電現象は中間電極とアース電極と の間に形成されるキャパシタの大きさに依存していると 考えられる。レーザー発振にとって適切なキャパシタの 大きさは高速高電圧固体スイッチの電圧や充電電圧の大 きさによって変化すると思われるため, 最適化は難しい が，概ねアース電極より 10-30 mm程度の距離に中間電 極を設置するのが望ましいことが分かった。

\section{6. まとめ}

軸方向放電励起炭酸ガスレーザーを製作し，中間電極 に高速高電圧固体スイッチを接続することによってレー ザー発振を実現させた，本方式では，放電管そのものが スイッチとして動作するため, 電源部のスイッチは不要 であり, レーザーの小型化, 低コスト化の推進を可能と する。また，固体スイッチは本質的にメンテナンスフ リーであり，ジッ夕が少なく，高繰り返し動作が可能で あり，レーザーの高性能化にも寄与する，放電長，充電 電圧，高速高電圧固体スイッチの電圧，立ち上がり時間 等, 最適化を行う必要があるが，今後検討する。また， 本研究ではレーザー媒質として炭酸ガスを用いたが，励 起条件や放電条件を整えることで，窒素等，他の軸方向 放電励起気体レーザーにおいても本方式は適用可能であ ると考えられる。 


\section{参考文献}

1) M. Geleer, D. E. Altman, and T. A. Detemple: J. Appl. Phys. 37 (1966) 3639.

2) M. A. El-Osealy, T. Ido, K. Nakamura, T. Jitsuno, and S. Horiguchi: Opt. Commun. 194 (2001) 191.

3) M. A. M. El-Osealy, T. Jitsuno, K. Nakamura, and S. Horiguchi:
Opt. Commun. 205 (2002) 377.

4) M. A. M. El-Osealy, T. Jitsuno, K. Nakamura, Y. Uchida, and T. Goto: Opt. Commun. 207 (2002) 255.

5) K. Uno, H. Hayashi, T. Akitsu, and T. Jitsuno: J Infrared Milli Terahz Waves. 34 (2013) 217.

6) 中野人志, 岡本明, 藤本 恭史, 山田誠：レーザー研究 36 (2008) 584. 